\title{
Uji Aktivitas Antibakteri Salep Ekstrak Kulit Batang Kesambi (Schleichera oleosa Merr) terhadap Staphylococcus aureus ATCC 25923 yang Diinfeksikan pada Kelinci
}

\author{
Antibacterial Activity Test of Kesambi (Schleichera oleosa Merr) Bark Extract Ointment Against \\ Staphylococcus aureus ATCC 25923 Infected in Rabbits \\ Anastasia P Dhego ${ }^{1}$, Lina Susanti ${ }^{2}$, dan D. Andang Arif Wibawa ${ }^{2 *}$ \\ ${ }^{1}$ Fakultas Farmasi Universitas Setia Budi Surakarta \\ ${ }^{2}$ Fakultas Ilmu Kesehatan, Universitas Setia Budi Surakarta \\ *Corresponding author: andangface@yahoo.com
}

\begin{abstract}
ABSTRAK
Tujuan penelitian ini adalah untuk mengetahui aktivitas antibakteri salep ekstrak etanolik kulit batang kesambi (Scheichera oleosa Merr.) dan konsentrasi yang efektif dari salep ekstraknya pada kulit punggung kelinci yang terinfeksi Staphylococcus aureus ATCC 25923.

Ekstraksi dilakukan secara maserasi menggunakan pelarut etanol 70\%. Formula salep ekstrak kulit batang kesambi dibuat dengan basis hidrokarbon dengan tiga konsentrasi yaitu 6,25\%, 12,5\% dan 25\% dengan salep Gentamicin sebagai kontrol positif. Pengamatan waktu penyembuhan dilakukan dengan cara mengamati lamanya penyembuhan infeksi pada kulit punggung kelinci setelah pemberian salep ekstrak kulit batang kesambi yang ditandai dengan hilangnya eritema dan nanah. Data yang diperoleh dianalisis dengan ANOVA satu jalan (signifikansi p<0,05).

Hasil dari penelitian menunjukan bahwa salep ekstrak kulit batang kesambi memiliki efektivitas pada penyembuhan infeksi bakteri Staphylococcus aureus dan terdapat perbedaan efektivitas pada setiap konsentrasi. Konsentrasi salep ekstrak kulit batang kesambi 25\% memberikan efek penyembuhan yang lebih efektif dibandingkan dengan konsentrasi $12,5 \%$ dan $6,25 \%$.
\end{abstract}

Kata kunci: kulit batang kesambi, antibakteri, Staphylococcus aureus ATCC 25923.

\section{ABSTRACT}

The aim of the study was to find out the antibacterial activity of kesambi (Scheichera oleosa Merr.) bark ethanol extract ointment and the effective concentration against Staphylococcus aureus ATCC 25923 infected on the back skin of rabbits.

The extraction was done by maceration using ethanol 70\%. Formulas of kesambi bark extract ointment were made with hydrocarbon basic in three concentrations i.e. $6.25 \%, 12.5 \%$ and $25 \%$, with gentamycin ointment as positive control. Observation of healing time was done by observing the length of healing infection of the skin on the back skin of rabbits, after administration of kesambi bark extract ointment kesambi characterized by the loss of erythema and puss. The obtained data was analyzed using Paired-samples one way ANOVA (significance $p<0.05$ ).

The results showed that kesambi bark extract ointment kesambi had the effectiveness in healing Staphylococcus aureus bacterial infection and there were differences of effectiveness in each concentration. The healing effect of kesambi bark extract ointment in concentration of $25 \%$. Was more than the concentration of $12.5 \%$ and $6.25 \%$.

Keywords: kesambi bark ointment, antibacterial, Staphylococcus aureus ATCC 25923.

\section{PENDAHULUAN}

Tanaman di Indonesia banyak dimanfaatkan sebagai obat, salah satunya adalah tanaman kesambi. (Bachli, 2007). Kandungan kimia tanaman kesambi (Schleichera oleosa Merr) antara lain alkaloid, saponin dan tanin (Hutapea, 1994) yang diduga mempunyai aktivitas antibakteri. Antibakteri merupakan zat yang dapat menghambat atau membunuh bakteri dengan penyebab infeksi. Salah satu bakteri yang dapat menyebabkan infeksi adalah Staphylococcus aureus. Staphylococcus aureus merupakan flora normal yang dapat ditemukan pada kulit dan saluran pernapasan. Staphylococcus aureus bersifat Gram positif. Infeksi Stahpylococcus aureus biasanya terjadi 
pada luka terbuka atau luka potong (Jawetz et al., 2013).

Penelitian sebelumnya menunjukkan, bahwa ekstrak etanol 70\% kulit batang kesambi (Schleichera oleosa Merr) memiliki aktivitas antibakteri terhadap Staphylococcus aureus secara in vitro dengan konsentrasi 6,25\% (Fernandez, 2014), triterpenoid dari kulit batang kesambi yaitu taraxerone dan tricadenic acid $A$ memiliki aktivitas antibakteri terhadap Staphylococcus aureus (Ghosh et al., 2011).

Kulit batang kesambi memiliki aktivitas sebagai antimikroba, sehingga dapat ditingkatkan pemanfaatannya dengan memformulasikan menjadi sediaan farmasi yaitu sediaan salep yang dapat digunakan secara topikal untuk menyembuhkan kulit punggung kelinci yang terinfeksi bakteri Staphylococcus aureus.

\section{METODE PENELITIAN}

\section{Populasi dan Sampel}

Populasi yang digunakan dalam penelitian adalah kulit batang kesambi yang diambil dari daerah Larantuka, Nusa Tenggara Timur.

Sampel yang digunakan dalam penelitian ini adalah kulit batang tanaman kesambi (Schleichera oleosa Merr.) dengan ciri-ciri berwarna coklat dan bebas dari penyakit diambil dari daerah Larantuka, Nusa Tenggara Timur.

\section{Bahan dan Alat}

Alat yang digunakan dalam penelitian ini meliputi: alat timbang analitik yang mempunyai ketelitian baca minimum $0,1 \mathrm{mg}$ dan daya muat maksimum 100 gram, entkas, ose platina, piring petri, tabung reaksi, gelas ukur, erlenmeyer, pipet tetes, neraca analitis, pipet volume $(10 \mathrm{ml}$; $5 \mathrm{ml} ; 1 \mathrm{ml} ; 0,5 \mathrm{ml}$ ), siring, pinset, inkubator, mortir, stamper, kertas saring, kapas, corong kaca, autoklaf, mikroskop, kaca obyek, deglas, cawan petri, kasa steril dan sudip.

Bahan kimia yang digunakan adalah etanol
$70 \%$, basis salep vaselin album, $\mathrm{HCl} 2 \mathrm{~N}$, larutan $\mathrm{KOH} \quad 0,1 \mathrm{~N}$, larutan $\mathrm{NaCl} 0,9 \%$, larutan fenolptalein, kalium tellurite, larutan asetat anhidrat, asam klorida (1:1), asam asetat, $\mathrm{H}_{2} \mathrm{SO}_{4}$ pekat, besi (III) klorida, serbuk Mg, aquadest, alkohol, amil alkohol, feriklorida 1\%; Fehling A, Fehling B, media BHI (Brain Heart Infunsion), VJA (Vogel Johnson Agar), cat kristal violet, larutan lugol iodine.

\section{Jalannya Penelitian}

\section{Penetapan susut pengeringan serbuk kulit batang kesambi}

Penetapan susut pengeringan serbuk menggunakan alat Moisture Balance.

\section{Pembuatan ekstrak kulit batang kesambi}

Serbuk kulit batang kesambi ditimbang sebanyak 400 gram dimasukkan ke dalam botol maserasi dengan pelarut etanol $70 \%$ sebanyak $3000 \mathrm{ml}$, direndam selama 5 hari dan digojok beberapa kali sehari. Hasil maserasi disaring dengan kain flannel steril, ekstrak yang didapat dipekatkan di evaporator sampai memperoleh maserat yang kental.

\section{Pembuatan suspensi bakteri uji}

Bakteri uji Staphylococcus aureus diambil dari biakan pada media Nutrien Agar (NA) diambil kurang lebih 2 ose dan dibuat suspensi dalam tabung yang berisi $\mathrm{NaCl}$ fisiologis yang kekeruhannya disesuaikan dengan kekeruhan standard Mc. Farland 0,5 setara dengan jumlah bakteri $10^{8} \mathrm{CFU} / \mathrm{mL}$ (Bonang dan Koeswardono, 1982).

4. Pembuatan salep basis hidrokarbon dengan konsentrasi $6,25 \%, 12,5 \%$ dan $25 \%$ (Tabel 1)

\section{Pengujian sediaan salep}

a. Uji organoleptis.

Sediaan salep ekstrak kulit batang kesambi yang telah dibuat, diuji warna dan bau dengan memperhatikan adanya perubahan fisik selama penyimpanan.

\section{b. Uji daya lekat.}

Sediaan salep sebanyak 0,25 gram 
Tabel 1. Formula salep untuk uji antibakteri dengan basis hidrokarbon (Agoes 2008).

\begin{tabular}{cccc}
\hline Komposisi & \multicolumn{3}{c}{ Konsentrasi } \\
\cline { 2 - 4 } & Formula 1 (6,25\%) & Formula 2(12,5\%) & Formula 3 (25\%) \\
\hline Ekstrak kulit batang kesambi & $3,125 \mathrm{~g}$ & $3,75 \mathrm{~g}$ & $37,45 \mathrm{~g}$ \\
Vaselin album & $46,825 \mathrm{~g}$ & $46,2 \mathrm{~g}$ & $70 \mathrm{~g}$ \\
Nipasol & Ad 50 & Ad 50 & Ad 50 \\
\hline Keterangan: & \multicolumn{3}{c}{} \\
Formula 1 (F1) = Salep Ekstrak Kulit Batang Kesambi konsentrasi $6,25 \%$ \\
Formula 2 (F2) = Salep Ekstrak Kulit Batang Kesambi konsentrasi 12,5\% \\
Formula 3 (F3) = Salep Ekstrak Kulit Batang Kesambi konsentrasi 25\%
\end{tabular}

diletakkan di atas gelas obyek yang telah ditentukan luasnya kemudian diletakan gelas obyek yang lain di atas salep tersebut. Salep di antara lempeng gelas obyek ditekan dengan beban $0,5 \mathrm{~kg}$ selama 5 menit. Gelas obyek yang saling menempel dipasang pada alat uji daya lekat dan dilepas dengan beban seberat 80 gram, kemudian dicatat waktu saat kedua gelas obyek tersebut lepas.

\section{c. Uji daya sebar.}

Sediaan salep ditimbang 0,5 gram, diletakkan pada pusat antara dua lempeng kaca extensometer, dibiarkan selama 1 menit lalu ukur diameter salep yang menyebar. Anak timbangan 50 gram ditambahkan pada lempeng sebelah atas, didiamkan 1 menit, dicatat diameter salep yang menyebar, diulangi masing-masing dengan penambahan sampai beban 200 gram pada tiap salep yang diperiksa (Hernani et al., 2010).

\section{d. Uji viskositas.}

Viskometer di pasang pada klemnya dengan arah horizontal/tegak lurus dengan arah klem. Rotor dipasang pada viskotester dengan menguncinya berlawanan arah dengan jarum jam. Sampel dimasukkan ke dalam mangkuk, kemudian alat dihidupkan. Kekentalan yang di dapat di catat setelah jarum pada viskositas stabil.

\section{e. Uji Homogenitas.}

Sediaan salep sebanyak 0,5 gram diletakkan di atas obyek gelas kemudian diratakan dan diamati secara visual.

\section{f. Uji kemampuan proteksi.}

Sepotong kertas saring $(10 \times 10 \mathrm{~cm})$ dibasahi dengan larutan fenolptalein untuk indikatornya, kemudian kertas saring dikeringkan. Kertas saring tersebut diolesi dengan salep kulit batang kesambi. Kertas saring tersebut dibuat suatu areal $(2,5 \times 2,5 \mathrm{~cm})$ pada kertas saring yang lain dengan parafin padat yang dilelehkan. Kertas saring tadi setelah kering/dingin akan didapat areal yang dibatasi dengan paraffin padat. Kertas saring tersebut ditempelkan di atas kertas saring yang diolesi salep kulit batang kesambi. Areal ini ditetesi dengan sedikit larutan $\mathrm{KOH}$ $0,1 \mathrm{~N}$. Dilihat dibalik kertas yang dibasahi dengan larutan fenolptalein pada waktu $15: 30$ : $45: 60$ detik : 3 dan 5 menit. Kertas saring tersebut apabila ada noda berwarna merah/kemerahan pada kertas tersebut berarti salep dapat memberikan proteksi terhadap larutan $\mathrm{KOH}$.

\section{g. Uji pH salep.}

Pengujian dilakukan dengan mencelupkan pH stik kedalam sediaan salep ekstrak kulit batang kesambi, didiamkan selama 1 menit. Perubahan warna pada $\mathrm{pH}$ stik menunjukan nilai $\mathrm{pH}$ dari salep.

\section{Pengujian Efek Antibakteri.}

Hewan uji yang digunakan dalam penelitian ini adalah kelinci sebanyak 5 ekor dengan umur \pm 3 bulan dengan berat $\pm 1,5-2 \mathrm{~kg}$. Hewan uji kelinci yang sudah diaklimatisasikan selama 5 hari dicukur bulu pada punggung kelinci kemudian dipilih 5 lokasi penyuntikan dibagian kiri dengan jarak masing-masing lokasi $\pm 5 \mathrm{~cm}$. Suspensi Staphylococcus aureus diinfeksikan secara subkutan sebanyak $0,2 \mathrm{ml}$ pada masingmasing lokasi pada kulit punggung kelinci yang 
telah disiapkan. Salep diberikan setelah 72 jam pada daerah yang diinfeksi. Salep ekstrak kulit batang kesambi dengan konsentrasi 6,25\%, $12,5 \%$ dan $25 \%$ dioleskan pada 3 lokasi dibagian kiri punggung kelinci, 2 lokasi dibagian kanan sebagai kontrol negatif dioleskan dengan basis salep hidrokarbon dan kontrol positif dioleskan dengan salep gentamicin $0,1 \%$. Pengolesan salep ekstrak kulit batang kesambi dilakukan 3 kali sehari dengan rentang waktu 8 jam, pengamatan waktu penyembuhan infeksi berdasarkan hilangnya eritema dan nanah (Naibaho et al., 2013).

\section{Analisis Data}

Data hasil pengujian efek sediaan salep ekstrak etanol kulit batang kesambi (Schleichera oleosa Merr.) dengan konsentrasi 6,25\%, 12,5\% dan 25\% dengan lamanya waktu penyembuhan dan data uji daya sebar, daya lekat, dan daya viskositas dianalisis secara statistik menggunakan ANOVA satu jalan dan dilanjutnkan dengan Metode KolmogrovSmirnov.

\section{HASIL DAN PEMBAHASAN}

\section{a. Hasil uji organoleptis (Tabel 2)}

Hasil pengamatan terhadap basis salep dan sediaan salep dari segi warna dan menunjukan perbedaan dari masing-masing variasi konsentrasi. Semakin tinggi konsentrasi ekstrak warna sediaan semakin tua. Sedangkan pengamatan terhadap bau sediaan salep memiliki bau khas yang sama yakni bau khas dari ekstrak kulit batang kesambi dengan konsistensi semi padat.

\section{b. Hasil uji daya lekat (Tabel 3)}

Hasil pengamatan menunjukan bahwa formula 3 memiliki daya lekat yang paling lama dibandingkan formula 2 dan formula 1 . Semakin besar nilai daya lekat sediaan ketika diujikan, maka kemampuan melekat pada kulit semakin kuat dan absorbsi dikulit akan semakin besar karena ikatan antara salep dan kulit akan semakin lama, sehingga zat aktif obat akan terlepas secara lebih optimal.

\section{c. Hasil uji daya sebar (Tabel 4)}

Tabel 4 menunjukan bahwa setiap penambahan beban pada pengujian daya sebar terjadi peningkatan diameter penyebaran salep ekstrak kulit batang kesambi, karena luas penyebaran berbanding lurus dengan kenaikan beban yang ditambahkan, semakin besar beban yang ditambahkan maka luas penyebaran makin besar. Perbedaan daya sebar sangat

Tabel 2. Hasil pengujian organoleptis formula salep ekstrak etanol 70\% kulit batang kesambi

\begin{tabular}{|c|c|c|c|c|c|c|}
\hline \multirow{3}{*}{$\begin{array}{c}\text { Hasil } \\
\text { pengamatan } \\
\text { salep (minggu) }\end{array}$} & \multicolumn{6}{|c|}{ Konsentrasi Formula } \\
\hline & \multicolumn{2}{|c|}{ F $1(6,25 \%)$} & \multicolumn{2}{|c|}{ F $2(12,5 \%)$} & \multicolumn{2}{|r|}{ F $3(25 \%)$} \\
\hline & Bau & Warna & Bau & Warna & Bau & Warna \\
\hline 1 & Khas & Merah tua & Khas & Merah tua & Khas & Merah tua kehitaman \\
\hline 2 & Khas & Merah tua & Khas & Merah tua & Khas & Merah tua kehitaman \\
\hline 3 & Khas & Merah tua & Khas & Merah tua & Khas & Merah tua kehitaman \\
\hline 4 & Khas & Merah tua & Khas & Merah tua & Khas & Merah tua kehitaman \\
\hline \multicolumn{7}{|c|}{ Tabel 3. Hasil uji daya lekat salep ekstrak kulit batang kesambi } \\
\hline Waktu & \multicolumn{3}{|c|}{ Formula $1(12,5 \%)($ detik$)$} & \multicolumn{2}{|c|}{ Formula $2(12,5 \%)($ detik $)$} & Formula $3(25 \%)$ (detik) \\
\hline Minggu ke-1 & \multicolumn{3}{|c|}{$101,66 \pm 0,57$} & \multicolumn{2}{|c|}{$109,33 \pm 1,15$} & $131,33 \pm 0,57$ \\
\hline Minggu ke-2 & \multicolumn{3}{|c|}{$118,66 \pm 0,57$} & \multicolumn{2}{|c|}{$125,66 \pm 0,57$} & $147,66 \pm 0,57$ \\
\hline Minggu ke-3 & \multicolumn{3}{|c|}{$130,66 \pm 0,57$} & \multicolumn{2}{|c|}{$136,66 \pm 0,57$} & $157,66 \pm 0,57$ \\
\hline Minggu ke-4 & \multicolumn{3}{|c|}{$141,33 \pm 0,57$} & \multicolumn{2}{|c|}{$150,66 \pm 0,57$} & $168,66 \pm 0,57$ \\
\hline \multicolumn{7}{|c|}{ Tabel 4. Hasil uji daya sebar salep ekstrak kulit batang kesambi } \\
\hline Konsentrasi & \multicolumn{2}{|c|}{ Minggu 1} & \multicolumn{2}{|c|}{ Minggu 2} & Minggu 3 & Minggu 4 \\
\hline $6,5 \%$ & & 3,9 & \multicolumn{2}{|c|}{3,6} & 3,43 & 3,23 \\
\hline $12,5 \%$ & & 3,7 & \multicolumn{2}{|c|}{3,47} & 3,23 & 3,03 \\
\hline $25 \%$ & & 3,5 & \multicolumn{2}{|c|}{3,1} & 2,93 & 2.83 \\
\hline
\end{tabular}


mempengaruhi kecepatan difusi zat aktif dalam melewati membran. Semakin luas daya sebar maka difusi salep meningkat, sehingga semakin besar daya sebar sediaan maka semakin baik. Luas penyebaran sediaan salep berhubungan dengan konsistensi atau viskositas sediaan, semakin besar viskositas salep maka daya sebar semakin kecil.

\section{d. Hasil uji viskositas (Tabel 5)}

Tabel 5 menunjukan bahwa viskositas formula 3 lebih besar dibandingkan dengan Formula 2 dan Formula 1. Peningkatan viskositas salep dalam penelitian ini dipengaruhi suhu selama masa penyimpanan.

\section{e. Hasil uji homogenitas (Tabel 6)}

Tabel 6 menunjukan hasil bahwa salep ekstrak kulit batang kesambi menunjukan susunan yang homogen selama masa penyimpanan yaitu minggu ke-1 sampai minggu ke-4. sediaan dikatakan homogen apabila terbukti tidak terdapat partikel-partikel yang menggumpal serta memiliki warna yang merata pada seluruh bagian salep (Lachman, 2008) dan dasar salep, bahan aktif serta bahan tambahan lain tercampur merata.

\section{f. Hasil uji kemampuan proteksi (Tabel 7)}

Uji kemampuan proteksi salep ekstrak kulit batang kesambi menunjukan bahwa kemampuan proteksi Formula 3 lebih lama dibandingkan Formula 2 dan Formula 1, dapat dilihat dari bercak merah yang timbul setelah diberikan zat asing. Hal ini disebabkan konsistensi atau viskositas formula 3 lebih kental, sehingga ikatan antar partikel menjadi lebih rapat dan susah ditembusi oleh zat asing yang mana pada penelitian ini digunakan $\mathrm{KOH}$.

\section{g. Hasil uji pH salep (Tabel 8)}

Uji pH salep ekstrak kulit batang kesambi dilakukan pada hari ke 1 dan hari ke 7 pada masing-masing konsentrasi formula. Didapati pH pada Formula 1, Formula 2, dan Formula 3 pada hari ke 1 memiliki $\mathrm{pH}$ yang sesuai dengan kriteria $\mathrm{pH}$ kulit yaitu 6 sementara nilai $\mathrm{pH}$ pada hari ke 7 menunjukan hasil yang serupa, sehingga Formula aman digunakan karena $\mathrm{pH}$ yang terlalu asam dapat mengiritasi kulit sedangkan $\mathrm{pH}$ yang terlalu basa dapat membuat kulit bersisik.

\section{h. Hasil Pengujian Aktivitas Antibakteri secara in vivo (Tabel 9)}

Tabel 9 menunjukan hasil pengamatan secara makroskopis dengan berkurangnya gejala klinis dan waktu penyembuhan infeksi bakteri Staphylococcus aureus pada kulit punggung kelinci dengan pemberian tiga konsentrasi salep ekstrak kulit batang kesambi,

Tabel 5. Hasil uji viskositas salep ekstrak kulit batang kesambi

\begin{tabular}{ccccc}
\hline Konsentrasi & Minggu 1 & Minggu 2 & Minggu 3 & Minggu 4 \\
\hline $6,25 \%$ & 243,33 & 256,66 & 253,33 & 273,33 \\
$12,5 \%$ & 266,66 & 278,33 & 290 & 303,33 \\
$25 \%$ & 306,66 & 316,66 & 333,33 & 346,66 \\
\hline \multicolumn{5}{c}{ Tabel 6. Hasil uji homogenitas salep ekstrak kulit batang kesambi } \\
\hline Formula & Minggu ke-1 & Minggu ke-2 & Minggu ke-3 & Minggu ke-4 \\
\hline Formula 1 (6,25\%) & Homogen & Homogen & Homogen & Homogen \\
Formula 2 (12,5\%) & Homogen & Homogen & Homogen & Homogen \\
Formula 3 $(25 \%)$ & Homogen & Homogen & Homogen & Homogen \\
\hline
\end{tabular}

Tabel 7. Hasil uji kemampuan proteksi salep ekstrak kulit batang kesambi

\begin{tabular}{cccc}
\hline \multirow{2}{*}{ Pemeriksaan waktu } & \multicolumn{3}{c}{ Hasil uji proteksi salep (detik) } \\
\cline { 2 - 4 } & Formula 1 (6,25\%) & Formula 2 (12,5\%) & Formula 3 $(25 \%)$ \\
\hline Minggu ke-1 & 10 & 17 & 34 \\
Minggu ke-2 & 11 & 19 & 35 \\
Minggu ke-3 & 10 & 19 & 35 \\
Minggu ke-4 & 10 & 17 & 36 \\
\hline
\end{tabular}


Tabel 8. Hasil uji pH salep ekstrak kulit batang kesambi



kontrol positif (salep gentamicin) dan kontrol negatif (basis salep) sebagai parameter untuk mengetahui mana yang memiliki daya aktivitas antibakteri paling optimal terhadap infeksi Staphylococcus aureus pada kulit punggung kelinci Salep ekstrak kulit batang kesambi dengan konsentrasi terendah yaitu 6,25\% dapat menyembuhkan dalam waktu 16-18 hari. Konsentrasi $12,5 \%$ dapat menyembuhkan dalam waktu 14-16 hari. Konsentrasi tertinggi yaitu $25 \%$ dapat menyembuhkan dalam waktu 8-10 hari. Kontrol positif dapat menyembuhkan dalam waktu 8-10 hari. Kontrol negatif dapat menyembuhkan dalam waktu 20-22 hari. Daya aktivitas antibakteri dapat dilihat dari waktu penyembuhan paling cepat.

Berdasarkan hasil yang diperoleh dianalisis datanya menggunakan uji ANOVA terhadap hasil pengamatan waktu penyembuhan dengan taraf kepercayaan $95 \%$ terhadap perbedaan yang signifikan. Data infeksi bakteri Staphylococcus aureus dari ketiga formula, kontrol positif dan kontrol negatif diuji menggunakan uji Kolmogrov-Smirnov untuk mengetahui apakah data tersebut terdisdtribusi normal atau tidak. Hasil yang diperoleh dari analisis data waktu penyembuhan infeksi menunjukan nilai sig $0,140>0,05$ sehingga dapat disimpulkan bahwa data terdistribusi normal. Selanjutnya dilakukan uji ANOVA satu jalan untuk mengetahui adanya perbedaan waktu penyembuhan infeksi ketiga formula, kontrol positif dan kontrol negatif. Berdasarkan hasil test homogenitas data waktu penyembuhan infeksi dinyatakan homogen dengan nilai sig 0,195 $>0,05$. Hasil uji ANOVA satu jalan menunjukan F3 dengan $\mathrm{K}(+)$ memiliki pengaruh yang sama dalam waktu penyembuhan infeksi terlihat dari nilai sig 0,872 , sedangkan yang lain tidak memiliki pengaruh yang sama.

Berdasarkan data hasil waktu penyembuhan infeksi ekstrak kulit batang kesambi konsentrasi $25 \%$ sebanding dengan salep gentamicin sebagai kontrol positif. Gentamicin termasuk antibakteri golongan aminoglikosida yang memiliki spectrum luas dan bersifat bakteriasid dengan mekanisme penghambatan pada sintesis protein.

Salep ekstrak kulit batang kesambi dengan konsentrasi $6,25 \%$ dan $12,5 \%$ memiliki efek penyembuhan di bawah salep ekstrak kulit batang kesambi konsentrasi 25\% dan kontrol positif. Meskipun memiliki kandungan zat aktif tetapi jumlah zat aktif yang terkandung hanya sedikit sehingga lambat dalam penyembuhan infeksi bakteri pada kelinci. Konsentrasi 25\% mengalami waktu penyembuhan tercepat karena mengandung banyak zat aktif sebagai antibakteri seperti triterpenoid, tanin, alkaloid 
dan saponin. Perlakuan negatif dengan basis salep hidrokarbon berupa vaselin album memiliki daya penyembuhan infeksi paling lama dibandingkan dengan salep ekstrak kulit batang kesambi konsentrasi 6,25\%. Kontrol negatif yang menggunakan vaselin album dan pengawet nipasol hanya memberikan efek melembabkan bagian atas kulit (Fetu, 2013). Pemakaian basis salep pada infeksi Staphylococcus aureus memberikan efek penyembuhan yang paling lama karena tidak memiliki kandungan bahan aktif sebagai penyembuhan luka infeksi.

\section{PENUTUP}

\section{Kesimpulan}

Pertama, salep ekstrak kulit batang kesambi memiliki aktivitas antibakteri secara in vivo terhadap Staphylococcus aureus ATCC 25923 pada hewan kelinci.

Kedua, konsentrasi salep ekstrak kulit batang kesambi dengan waktu penyembuhan tercepat adalah konsentrasi $25 \%$ dengan waktu 9 hari.

\section{Saran}

Pertama, perlu dilakukan pengujian aktivitas antibakteri ekstrak etanol 70\% kulit batang kesambi terhadap bakteri patogen lainnya.

Kedua, perlu dilakukan penelitian lebih lanjut dari ekstrak kulit batang kesambi sebagai antibakteri dengan bentuk sediaan yang berbeda.

\section{DAFTAR PUSTAKA}

Agoes, G. 2008. Pengembangan Sediaan Farmasi. ITB-Press, Bandung.

Bachli, Y. 2007. Tanaman Kesambi dan Beternak Kutu Untuk Kesejahteraan. Buletin BPTP, Volume 1(3). Sulawesi Selatan.

Bonang G dan Koeswardono. 1982. Mikrobiologi Kedokteran Untuk Laboratorium Dan Klinik. PT. Gramedia. Jakarta. hlm 114-116, 176-191.

Fernandez R. 2014. Uji Aktivitas Antibakteri Fraksi n-heksan, Fraksi Kloroform Dan Fraaksi Air Dari Ekstrak Etanolik Kulit Batang Kesambi (Schleichera oleosa Merr.) Terhadap Bakteri Staphylococcus aureus ATCC 25923 Secara in vitro [Skripsi]. Surakarta: Fakultas Farmasi, Universitas Setia Budi.

Fetu TB. 2013. Uji aktivitas antibakteri salep ekstrak etil umbi sarang semut (Hydnophyum formicarum Jack.) terhadap Pseudomonas aeruginosa ATCC 27853 secara in vivo [Skripsi]. Surakarta: Fakultas Farmasi, Universitas Setia Budi.

Ghosh P, Chakraborty P, Saha A. 2011. Triterpenoids from Schleichera oleosa of Darjeeling Foothills and Their Antimicrobial Activity. Indian Journal of Pharmaceutical Sciences. 73(2): 231-233.

Hernani MY, Mufrod, Sugiyono. 2012. Formulasi Salep Ekstrak Air Tokek (Gekko gecko L.) Untuk Penyembuhan Luka. Yogyakarta: Fakultas Farmasi. Universitas Gajah Mada.

Hutapea JR. 1994. Iventaris Tanaman Obat Indonesia III. Departemen Kesehatan Republik Indonesia. hlm 249.

Jawetz E, Melnick. J.L, Adelberg. E.A. 2013. Mikrobiologi Kedokteran. Edisi 25. Penerbit Buku Kedokteran EGC. Jakarta. Hlm 194-200.

Lachman, L. 2008. Teori dan Praktek Farmasi Industri. Jakarta: UI-Press

Naibaho, O.H., Yamlean, P.V.Y., Wiyono, W. 2013. Pengaruh Basis Salep terhadap Formulasi Sediaan Salep Ekstrak Daun Kemangi (Ocimum sanctum L.) pada Kulit Punggung Kelinci yang dibuat Infeksi Staphylococcus aureus. Manado: Program Studi Farmasi, FMIPA UNSRAT. 